Reprod. Nutr. Dévelop., 1987, 27 (6), 1013-1021.

\title{
Lack of effect of a high polyunsaturated fat diet on the growth of transplantable colon tumors and on the cytolytic activity of macrophages in rats
}

\author{
Danièle REISSER ( ${ }^{1}$ ), Patricia LAGADEC, Hélène PELLETIER, Catherine FADY, \\ N. O. OLSSON, J. F. JEANNIN
}

INSERM U 252, Faculté de Médecine, 7, bd J. d'Arc,

21033 Dijon, France.

Summary. The effect of a high dietary level of polyunsaturated fat was tested on the growth of three different colon cancer cell lines injected subcutaneously into syngeneic rats. This effect was also tested on the in vitro cytolytic activity of resident peritoneal macrophages, natural or endotoxin and/or indomethacin-modulated. A $12 \%$ corn oil dietary supplement had no effect in any of the cases tested.

\section{Introduction.}

A high level of dietary fat, particularly polyunsaturated fat, has been shown to have a promotional effect on colon carcinogenesis in rodents (Reddy, Weisburger and Winder, 1974 ; Reddy and Maeura, 1984). The proposed mode of action is through the effect of fat on luminal bile acids and the prostaglandin (PG) level (these are synthesized from polyunsaturated fatty acids) which may modulate the immune response (Johnston, 1985).

The aim of this work was to study the effect of diets containing a normal or a high level of polyunsaturated fat on the growth of subcutaneously inoculated colon cancer cells. This model, which prevents any contact between the tumor cells and the luminal content, does not explore the role of fatty acids on colon carcinogenesis, but their effect on the tumor cells, either directly or through a modulation of immune system activity. We used three fully transformed cell lines, differing in their in vivo behaviour.

As macrophages are involved in the immune response against tumors (Hibbs, Lambert and Remington, 1972), we tested their in vitro cytolytic activity against colon tumor cells; the effector cells were collected from rats fed either a normal or a high polyunsaturated fat diet. This assay was performed with or without indomethacin, an inhibitor of PG synthesis, and/or endotoxin (lipopolysaccharide : LPS), an activator of macrophage tumoricidal activity; the aim of the work was to

(1) To whom correspondence should be addressed. 
determine a possible effect of the diet on the natural or modulated cytolytic activity of the macrophages.

Dietary fat has been reported to act indirectly on immune response through modification of the serum composition rather than directly on the effector cells (Friend et al., 1980). Therefore, a second set of experiments was performed using normal or " fat " rat serum instead of fetal calf serum.

\section{Material and methods.}

Animals and diet. - Three month-old inbred BDIX rats, bred in our laboratory, were fed ad libitum a commercial rat chow (Extralabo, Pietrement, Provins, France) either unaltered or supplemented with $12 \%$ corn oil by weight. The normal fat diet contained $24.5,48.5$ and $5 \%$ of protein, carbohydrate and fat, respectively, while the high-fat diet contained $22,43.5$ and $15 \%$. The fatty acid distribution of the diets is given in table 1 . The rats lequal number of males and females per group) were given the diet four weeks before cell harvesting or the beginning of the tumorigenicity assay and were maintained on the diet throughout the study. Every other day the pellets were changed, and the number of left-over pellets was counted to evaluate the amount of food ingested.

TABLE 1

Fatty acid distribution of the diets $1 \%$.

\begin{tabular}{ccc} 
& Normal fat diet & High-fat diet \\
$14: 0$ & 1.1. & 0.3 \\
$16: 0$ & 19.3. & 15.3 \\
$16: 1$ & 0.8. & 0.3 \\
$18: 0$ & 6.8. & 3.4 \\
$18: 1$ & 20.4. & 25.1 \\
$18: 2$ & 46.2. & 52.9 \\
$18: 3$ & 4.5. & 2.0 \\
$20: 0$ & 0.5. & 0.6 \\
$20: 4$ & 0.4. & 0.1 \\
\hline
\end{tabular}

Cancer cells. - The cells used were the DHD K12/TR and DHD K12/TS permanent cell lines established in culture from a colon adenocarcinoma induced by dimethylhydrazine in a BDIX rat (Martin et al., 1983). We also used DHD $\mathrm{K} 12 / \mathrm{TRb}$ cells, cloned from the former cell line (Caignard et al., 1985). The DHD $\mathrm{K} 12 / \mathrm{TR}$ and TRb cells when injected in syngeneic rats induce progressive tumors which finally kill the animals, while the DHD K12/TS cells induce tumors which regress spontaneously in about 4 weeks.

In vivo experiments. - Each rat was subcutaneously injected in the thorax with $10^{6}$ cancer cells. The growth of the tumors was followed weekly by measuring their length and width with callipers to estimate their volume. After sacrifice, the rats were autopsied and examined for metastases. 
Gompertz coefficients (Simpson-Herren and Llyod, 1970) of the tumor growth curves were calculated to compare the growth kinetics of the tumors in rats fed the different diets.

In vitro experiments. - Cytolysis assays were performed as previously described (Jeannin, Olsson and Martin, 1983). Briefly, $10^{4}{ }^{3} \mathrm{H}$-thymidine-prelabeled cancer cells were incubated in wells of microtest plates for $72 \mathrm{~h}$, with or without $10^{5}$ peritoneal macrophages harvested from either normal or tumor-bearing rats. After vigorous washing the remaining viable adherent cells were lysed and their radioactivity was counted. Cytolysis was calculated according to the formula $100(a-b) / a$, where a was the mean radioactivity in the 8 control wells and $b$ the mean radioactivity in the 8 experimental wells. In each assay, macrophagemediated cytolysis was determined with or without the addition of LPS and/or indomethacin.

Cytolysis assays were performed in Ham F10 medium supplemented with $10 \%$ of either fetal calf serum or rat serum. The rat serum was collected by cardiac puncture from either "normal " rats or those in the postprandial period after a corn oil meal delivered by gastric intubation. The latter is referred to as "fat » serum.

Gas chromatography analysis. - The dietary fatty acids were quantified as methyl esters using a Packard 428 chromatograph (Downer groves IL) fitted with an OV 351 capillary column from Spiral Co, Couternon, France.

Statistics. - The significance of the differences between the Gompertz parameters of attenuation and the slope of the tumor growth curves depending on the diets was calculated using the Mann-Whitney U-test.

The statistical significance of cytolysis with or without LPS and indomethacin was calculated using Student's t-test. The significance of the indomethacin or LPS effect and of diet effect was checked using three-factor variance analysis.

Chemicals. - Endotoxins from E. coli were purchased from Difco (Detroit, MI), indomethacin from Sigma (St Louis, MO), Ham F10 medium was from Microbiological Associates (Walkersville, MD) and fetal calf serum Hy Clone from Sterile System (Logan, UT).

All media were checked by the Limulus Amebocyte Lysate assay to be sure they were endotoxin-free.

\section{Results.}

\section{In vivo experiments.}

The growth curves of the rats fed the two diets were similar. Those fed the high-fat diet reduced their food intake by $25 \%$. However, they ingested 2.5 times more polyunsaturated fatty acids than the rats fed the normal diet. 
Injection of $D H D K 12 / T R$ cells (10 rats per group). - Although the tumors grew faster in the rats fed the high-fat diet, the two groups of rats did not significantly differ as to tumor growth kinetics, expressed as a curve of mean tumor volume or as the Gompertz parameters of the individual growth curves (fig. 1). The large variation noted in each group is a usual phenomenon in this tumor model. Among the rats fed the normal diet, tumors began to grow in 2 rats and then disappeared within 8 weeks, while in the high-fat diet group the same phenomenon occurred in 4 rats. There was no difference in the number of rats bearing invaded lymph nodes ( 3 rats in each group) and pulmonary metastases (2 rats in each group).

As the tumor regression observed in a few animals could have masked the differences, another experiment was performed using the cloned line DHD K12/TRb which does not undergo regression.

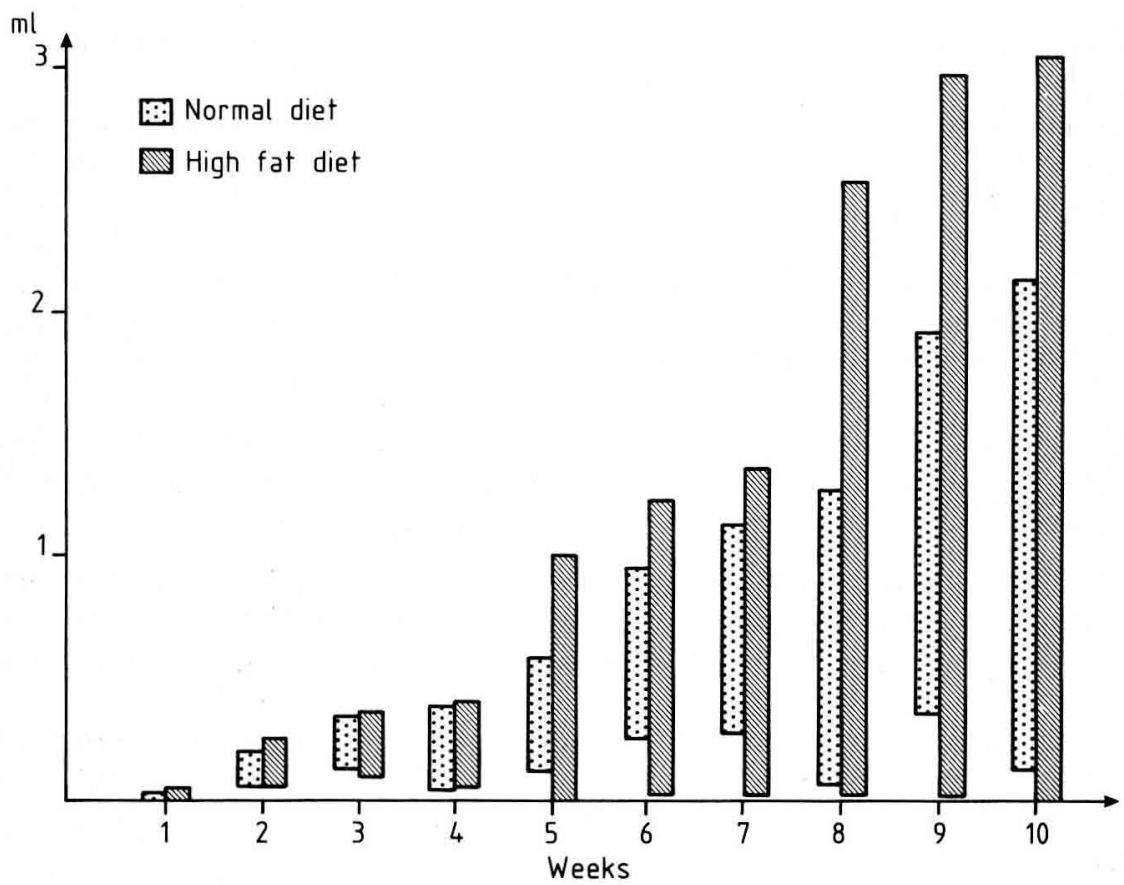

FIG. 1. - Growth curves of tumors from DHD $K 12 / T R$ cell inoculation. 10 rats $(5$ males and 5 females) per group. Mean - SD of the size values are reported on the figure. Mean $\pm S D$ of the Gompertz parameters are :

Normal fat diet High-fat diet attenuation

$0.104 \pm 0.070$

$0.076 \pm 0.094$ and slope

Injection of $D H D K 12 / T R b$ cells (10 rats per group). - Here again, the tumors grew slightly faster in rats fed the high-fat diet but the difference was not significant (fig. 2). No tumor regressed. There was no difference in the number 
of rats bearing invaded lymph nodes ( 5 in each group) and pulmonary metastases (2 rats in each group).

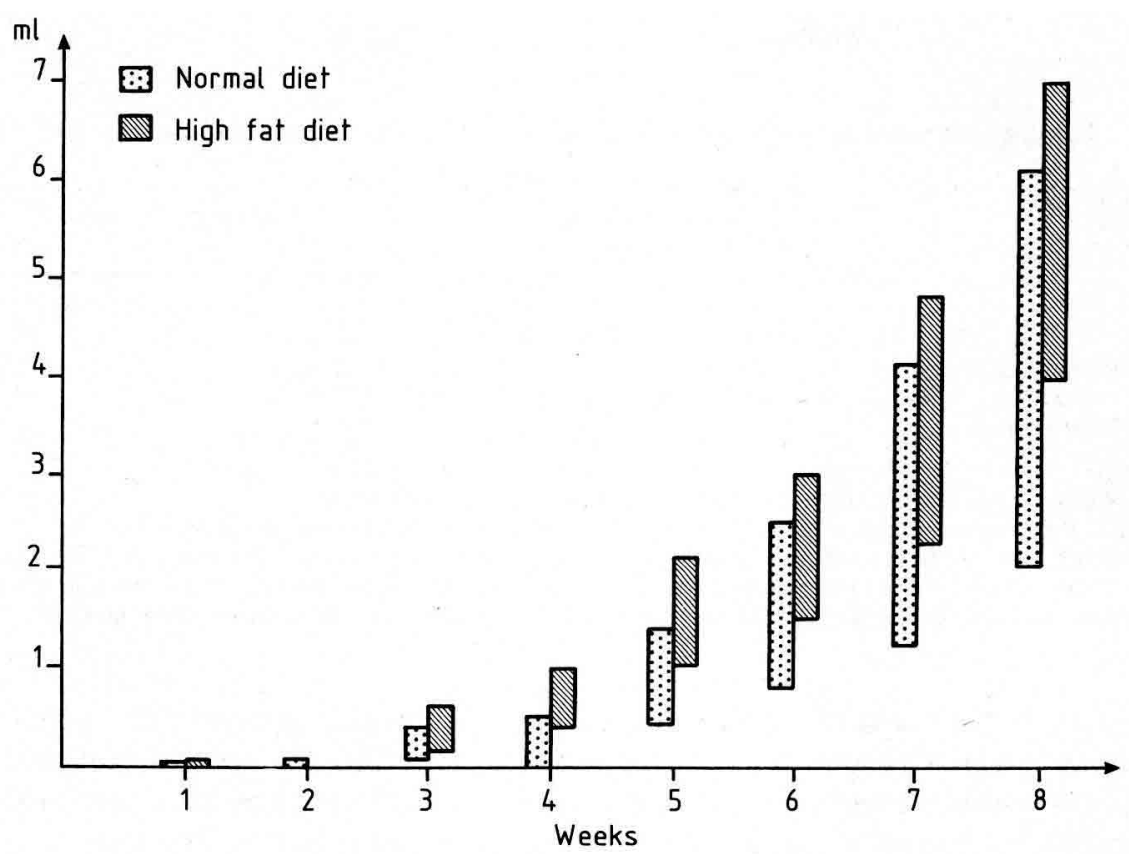

FIG. 2. - Growth curves of tumors from DHD K12/TRb cell inoculation. 10 rats $(5$ males and 5 females) per group. Mean - SD of the size values are reported on the figure. Mean \pm SD of the Gompertz parameters are :

Normal fat diet

High-fat diet attenuation
$0.023 \pm 0.025$
$0.040 \pm 0.025$ and

$$
\begin{gathered}
\text { slope } \\
0.370 \pm 0.573 \\
0.561 \pm 0.634
\end{gathered}
$$

Injection of DHD K12/TS cells (10 rats per group). - As expected, tumors grew in a progressive phase of 4-5 weeks, then regressed and disappeared. No significant difference was seen in tumor size between the groups receiving different diets. Although no tumor could be detected at 8 weeks, autopsy revealed that 3 rats from the high-fat group still bore at the injection site liver tumor nodules which underwent mitosis as determined by microscopy.

II. In vitro experiments.

Macrophages from rats fed the normal or high-fat diet 110 rats per group). - There was no significant influence of the diet on the cytolytic activity of either natural peritoneal macrophages or those modulated against DHD K12/TR and DHD K12/TS cell lines (table 2). Indomethacin significantly $(P<0.05)$ increased the cytolysis mediated by macrophages LPS-activated against 
DHD K12/TS in both diets. No significant dietary effects could be detected either when the macrophages were harvested from tumor-bearing rats at the time of sacrifice.

TABLE 2

Cytolysis mediated by peritoneal macrophages from rats fed a normal or high-fat diet.

\begin{tabular}{ccccc}
\hline \multirow{2}{*}{ Modulators } & \multicolumn{2}{c}{ DHD K12/TR cells } & \multicolumn{2}{c}{ OHD K12/TS cells } \\
\cline { 2 - 5 } & Normal diet & High-fat diet & Normal diet & High-fat diet \\
\hline 0 & $0 \pm 7$ & $-4 \pm 15$ & $0 \pm 7$ & $-2 \pm 5$ \\
Indomethacin $^{\mathrm{L}}$ & $-3 \pm 20$ & $-3 \pm 17$ & $-2 \pm 6$ & $-2 \pm 7$ \\
$\begin{array}{c}\text { Indomethacin } \\
+ \text { LPS }^{\mathrm{b}}\end{array}$ & $31 \pm 22^{\mathrm{cd}}$ & $21 \pm 16^{\mathrm{cd}}$ & $20 \pm 13^{\mathrm{cd}}$ & $19 \pm 8^{\mathrm{cd}}$ \\
\hline
\end{tabular}

Mean \pm SD of the cytolysis values in 10 independent experiments.

a : Indomethacin concentration of $10^{-8} \mathrm{~mole} / \mathrm{ml} ; \mathrm{b}$ : LPS concentration of $10 \mu \mathrm{g} / \mathrm{ml} ; \mathrm{c}$ : Significance of cytolysis level $(p<0.001)$ using Student's t-test in each experiment ; $d$ : Significance of LPS effect ( $p<0.001)$ using 3-factor variance analysis; $e$ : Significance of indomethacin effect on cytolysis mediated by LPS-activated macrophages $(P<0.05)$ using 3-factor variance analysis.

Effect of serum on macrophage cytolytic activity 16 rats per group). - Macrophages were harvested from rats fed the normal diet and the cytolysis assay was performed in a culture medium containing serum collected from either " normal » rats or from those given a corn oil meal. The serum had no significant effect on the cytolytic activity of the macrophages (table 3).

TABLE 3

Cytolysis mediated by peritoneal macrophages in presence of normal or "fat " rat serum.

\begin{tabular}{ccccc}
\hline \multirow{2}{*}{ Modulators } & \multicolumn{2}{c}{ DHD K12/TR cells } & \multicolumn{2}{c}{ DHD K12/TS cells } \\
\cline { 2 - 5 } & Normal serum & Fat serum & Normal serum & Fat serum \\
\hline 0 & $2 \pm 7$ & $2 \pm 9$ & $10 \pm 19$ & $-5 \pm 8$ \\
$\begin{array}{c}\text { Indomethacin } \\
\text { LPS }^{\mathrm{b}}\end{array}$ & $8 \pm 8$ & $6 \pm 9$ & $6 \pm 4$ & $1 \pm 7$ \\
$\begin{array}{c}\text { Indomethacin } \\
+ \text { LPS }^{\mathrm{a}}\end{array}$ & $25 \pm 12^{\mathrm{cd}}$ & $25 \pm 9 \mathrm{~cd}$ & $10 \pm 8 \mathrm{~cd}$ & $14 \pm 12^{\mathrm{cd}}$ \\
\hline
\end{tabular}

Mean \pm SD of the cytolysis values in 6 independent experiments.

a : Indomethacin concentration of $10^{-8} \mathrm{~mole} / \mathrm{ml} ; \mathrm{b}$ : LPS concentration of $10 \mu \mathrm{g} / \mathrm{ml} ; \mathrm{c}$ : Significance of cytolysis level $(p<0.01)$ using Student's t-test in each experiment ; $d$ : Significance of LPS effect ( $p<0.01$ ) using 3 -factor variance analysis.

\section{Discussion.}

Under our experimental conditions, diet did not significantly affect the growth of tumors induced by the injection of three cell lines originating from the same colon cancer, but with different tumorigenic potential. These data are in 
agreement with those of Nutter et al. (1983) who showed the lack of effect of the dietary fat level on the growth of tumors established by subcutaneous injection of colon cancer cells in mice. Even in primary chemo-induced colon tumors, the effect of dietary fat is not unequivocal. Reddy and Maruyama (1986) insisted on the promotional effect of a high level of dietary corn oil, while Nauss, Locniskar and Newberne (1983) and Locniskar et al. (1986) failed to detect any effect of the dietary fat level. Kroes et al. (1986) stated that the fat level had an influence only when the dietary fiber level was low.

High caloric diets have been shown to increase the incidence of spontaneous tumors in rats (Turnbull, Lee and Roe, 1985). In the present experiments, the diets were not isocaloric, the high-fat diet providing more calories than the normal one. In this respect, the rats fed the high-fat diet reduced their food intake, probably to equilibrate caloric intake. However, the high-fat diet did not increase tumor cell growth.

An effect of dietary fat on colon cancer through a modulation of PG synthesis has been suggested but data in the literature are controversial. While Pollard and Luckert (1980) and Narisawa et al. (1984) found that indomethacin reduced the incidence and growth of chemoinduced tumors in rats, Caignard et al. (1984) failed to see any indomethacin effect on either chemoinduced or transplanted colonic tumors.

Although not significant, the presence of surviving tumoral DHD K12/TS nodules may be linked to the immunodepressive effect of high-fat diets (Johnston, 1985), perhaps through a stimulation of PG synthesis. As macrophage sensitivity to PGE2 is influenced by dietary lipids (Opmeer, Adolfs and Bonta, 1984 ) and as PGE2 regulates the tumoricidal activity of macrophages (Taffet and Russel, 1981), we tested the cytolytic activity of macrophages harvested from rats fed the two diets. This was done in the presence or absence of indomethacin with or without LPS, a biological response modifier which activates macrophages and simultaneously makes them synthesize PGE2 (Kurland and Bockman, 1978). The high-fat diet altered neither natural nor LPS-modulated cytolytic activity and therefore did not act directly on it. The lack of difference in the effect of indomethacin on macrophages from animals on the two diets shows that fat did no affect the macrophages through PG synthesis. Furthermore, a polyunsaturated fatty acid-rich serum did not alter macrophage cytolytic activity, even against the DHD K12/TS cells, the survival of which they enhanced in vivo. Therefore, we can exclude any effect of the high-fate diet on macrophage cytolytic activity. Nutter et al. (1983) found that dietary fat had no influence on NK cell activity. Therefore, dietary fat does not seem to influence the response of cells from the immune system against tumor cells.

However our results do not imply that dietary fat level could not have an effect on in situ colon tumors by modifying bile acids, enzymes and/or microflora. 
Acknowledgments. - The authors wish to thank Pr. F. Martin for his interest throughout this study. They also wish to thank Ms A. Savadogo for excellent technical assistance, Ms L. Ramirez for revising the manuscript and Ms M. F. Michel for typing it.

Résumé. Absence d'effet d'un régime riche en graisses polyinsaturées sur la croissance de tumeurs coliques transplantables et l'activité cytolytique des macrophages chez le rat.

Nous avons étudié chez le rat l'effet d'un régime riche en lipides polyinsaturés, d'une part sur la croissance de tumeurs obtenues par injection sous-cutanée de cellules tumorales coliques syngéniques appartenant à trois lignées différant par leur devenir in vivo, et d'autre part sur l'activité antitumorale in vitro de macrophages péritonéaux résidents de rats, naturelle ou modulée par des endotoxines et/ou de l'indométhacine. Un apport de $12 \%$ d'huile de maïs ne modifie aucun des paramètres testés.

\section{References}

CAIGNARD A., MARTIN M. S., REISSER D., THOMAS B., MARTIN F., 1984. Effects of cimetidine and indomethacin on the growth of dimethylhydrazine-induced or transplanted intestinal cancers in the rat. Br. J. Cancer, 50, 661-665.

CAIGNARD A., MARTIN M. S., MICHEL M. F., MARTIN F., 1985. Interaction between two celiular subpopulations of a rat colonic carcinoma when inoculated to the syngeneic host. Int J. Cancer, 36, 273-275.

FRIEND J. V., LOCK S. O., GURR M. I., PARISH W. E., 1980. Effect of different dietary lipids on the immune response of Hartley strain guinea pigs. Int. Arch. Allergy appl. Immunol., 62, 292-301.

HIBBS J. B., LAMBERT L. H., REMINGTON J. S., 1972. Control of carcinogenesis : A possible role for the activated macrophages. Science, 177, 998-1000.

JEANNIN J. F., OLSSON N. O., MARTIN F., 1983. Liposome induction or enhancement of macrophage-mediated cancer cell lysis. Int. J. Cancer, 31, 75-80.

JOHNSTON P. V., 1985. Dietary fat, eicosanoid and immurity. Adv. Lipid Res., 21, 103-141.

KROES R., BEEMS R. B., BOSLAND M. C., BUNNICK G. S. J., SINKELDAM E. J., 1986. Nutritional factors in lung, colon and prostate carcinogenesis in animal models. Fed. Proc., 45, $136-141$.

KURLAND J. I., BOCKMAN R., 1978. Prostaglandin E production by human blood monocytes and mouse peritoneal macrophages. J. exp. Med., 147, 952-957.

LOCNISKAR M., NAUSS K. M., KAUFMANN P., NEWBERNE P. M., 1985. Interaction of dietary fat and route of carcinogen administration or 1,2-dimethylhydrazine-induced colon tumorigenesis in rats. Carcinogenesis, 6, 349-354.

MARTIN F., CAIGNARD A., JEANNIN J. F., LECLERC A., MARTIN M. S., 1983. Selection by trypsin of two sublines of rat colon cancer cells forming progressive and regressive tumors. Int. J. Cancer, 32, 623-627.

NARISAWA T., HERMANEK P., HABS M., SCHMAHL D., 1984. Reduction of carcinogenicity of $\mathrm{N}$-nitrosomethylurea by indomethacin and failure of resuming effect of prostaglandin E2 (PGE2) against indomethacin. J. Cancer Res. clin. Oncol., 108, 239-242.

NAUSS K. M., LOCNISKAR M., NEWBERNE P. M., 1983. Effect of alteration in the quality and quantity of dietary fat on 1.2, dimethylhydrazine-induced colon tumorigenesis in rats. Cancer Res., 43, 4083-4090.

NUTTER R. L., GRIDLEY D. S., KETTERING J. D., ANDRES M. L., APRECIO R. M., SLATER J. M., 1983. Modification of a transplantable colon tumour and immune responses in mice fed different sources of protein, fat and carbohydrate. Cancer Letters, 18, 49-62.

OPMEER F. A., ADOLFS M. J. P., BONTA I. L., 1984. Regulation of prostaglandin E2 receptors in vivo by dietary fatty acids in peritoneal macrophages from rats. J. Lipid Res., 25, 262-268.

POLLARD M., LUCKERT P. H., 1980. Indomethacin treatment of rats with dimethylhydrazineinduced intestinal tumours. Cancer Treat. Rep., 64, 1323-1327. 
REDDY B. S., MAEURA Y., 1984. Tumor promotion by dietary fat in azoxymethane-induced colon carcinogenesis in female F344 rats : influence of amount and source of dietary fat. $J$. nat. Cancer Inst., 72, 745-750.

REDDY B. S., MARUYAMA H., 1986. Effect of dietary fish oil on azoxymethane-induced colon carcinogenesis in male F344 rats. Cancer Res., 46, 3367-3370.

SIMPSON-HERREN L., LLOYD H., 1970. Kinetic parameters and growth curves for experimental tumor systems. Cancer Chemother. Rep., 54, 143-174.

TAFFET S. M., RUSSEL S. W., 1981. Macrophage-mediated tumor cell killing : regulation of expression of cytolytic activity by prostaglandin E. J. Immunol., 126, 424-427.

TURNBULL. G. J., LEE P. N., ROE F. J. C., 1985. Relationship of body-weight gain to longevity and to risk of development of nephropathy and neoplasia in Sprague-Dawley rats. Fed. Chem. Toxic., 23, 355-361. 